\title{
THE COMPARATIVE STUDY OF RAILWAY BRIDGE DESIGN LOAD BETWEEN PM 60/2012 AND EN 1991: 2-2003
}

\section{STUDI PERBANDINGAN DESAIN PEMBEBANAN JEMBATAN KERETA API ANTARA PM 60/2012 DAN EN 1991: 2-2003}

\author{
Willy Barasa', Thiya Fiantika1, Dwi Agus Purnomo', Wimpie A N Aspar' \\ ${ }^{1}$ Center of Technology for Transportation System and Infrastructure \\ Agency for the Assessment and Application of Technology \\ e-mail : willy.barasa@bppt.go.id
}

\begin{abstract}
In Referring to the government programs on the increasing speed of the JakartaSurabaya express train in 2017, problems arise in the field, namely the potential increase in freight transportation via the railway line where an increase in loading is required on the railway especially for the existing bridge. This Research was implemented by increasing of the loading of the standard PM 60/2012 bridge to be compared with the EN1991: 2/2003 standard. This research analyzed the increase in structural strength of the $30 \mathrm{~m}$ span steel bridge of the BH 182 constructed in Operational Region 2 Bandung as a results of loading adjustment from PM 60/2012 to EN 1991:2/2003. This paper explained an effect caused by increasing load on railway bridges with similar span and materials on normal plane, shear plane, moment and deflection. Structural analysis and calculation was performed by means of SAP2000 software. Results of analysis showed that standard equalization of EN 1991:2/2003 caused increasing percentage of loading combination of Comb L, normal plane, shear plane, moment plane, and deflection are of $35 \%, 60 \%, 71 \%$, and $31 \%$, respectively. While for Comb R loading combination for normal plane, shear plane, moment plane, and deflection are of $30 \%, 64 \%, 71 \%$, and $30 \%$, respectively.
\end{abstract}

Keywords : PM 60 of 2012; EN1991:2-2003; SAP2000; Normal Field; Shear Field; Moment Field; Deflection.

\begin{abstract}
Abstrak
Merujuk program Pemerintah pada peningkatan kecepatan kereta api ekspres Jakarta-Surabaya pada tahun 2017, muncul permasalahan di lapangan yaitu melonjaknya potensi peningkatan angkutan barang melalui jalur kereta api. Hal ini mengakibatkan peningkatan pembebanan jalur KA terutama pada jembatan eksisting. Untuk itu, sudah saatnya melakukan studi untuk mendukung program tersebut dengan melakukan peningkatan pembebanan jembatan standar PM 60/2012 untuk disetarakan dengan standard EN1991:2-2003. Penelitian ini menganalisis kenaikan kekuatan struktur jembatan rangka baja bentang $30 \mathrm{~m}$ pada bangunan $\mathrm{BH} 182$ yang berada pada kewenangan Daerah Operasi 2 Bandung akibat pemberlakuan peraturan pembebanan dari PM60/2012 ke EN 1991:2-2003. Makalah ini menjelaskan pengaruh yang ditimbulkan akibat peningkatan pembeban pada jembatan kereta api dengan bentang dan material yang sama pada bidang normal, bidang geser, bidang momen dan lendutan. Metode pelaksanaan studi mengacu pada analisis pembebanan jembatan yang tertuang dalam SNI1725:2016 tentang pembebanan jembatan. Hasil analisis menunjukkan bahwa penyetaraan standar EN 1991:2-2003 mengakibatkan persentasi peningkatan kombinasi pembebanan Comb $L$ yaitu bidang normal, bidang geser, bidang momen, dan lendutan berturut-turut sebesar 35\%, 60\%, $71 \%$, dan $31 \%$. Sedangkan untuk kombinasi pembebanan Comb $R$ berturut-turut untuk bidang normal $30 \%$, bidang geser $64 \%$, bidang momen $71 \%$, dan lendutan $30 \%$.
\end{abstract}

Kata kunci : PM 60 tahun 2012; EN1991:2-2003; SAP2000; Bidang Normal; Bidang Geser; Bidang Momen; Lendutan.

Received: 08 July 2020, Revised: 30 July 2020, Accepted: 14 August 2020

\section{INTRODUCTION}


and goods. Today, trains have been the most desirable transportation because they are free from traffic and have a shorter travel time compared to other land transportation modes. It is known that railroad transport is a type of transportation that moves on rails. Railroad created during the industrial revolution is a means of transportation to transport goods in large quantities and long distances. One freight car with axle load of 18 tons can load tens of tons of goods ${ }^{1}$. Train was introduced in Indonesia, during the Dutch colonial period. The first rail line was built by the Staats Spoorwegen (SS) company. The route was between SurabayaPasuruan along 115 kilometers and was inaugurated on May $16,1878{ }^{2)}$.

Referring to the National Railway Master Plan $^{3)}$, the target distribution of transportation is of $11-13 \%$ for passengers and freight transportation is of $15-17 \%$ accommodated by railway network of $10,000 \mathrm{kms}$, double tracks and electrification on the main traffic. Trains are targeted to be the backbone of integrated, safe, comfortable and affordable urban transportation. This is a business opportunity that needs to be optimized by PT. KAI.

Cities can be connected by railway facilities if supported by adequate and possible infrastructure, such as railway slope. In special conditions there are often crossings with slopes greater than the determining ramps. These special conditions are referred to as steep ramps with length of ramps that must meet the applicable provisions. ${ }^{4)}$

In overcoming slopes, various methods are engineered to make the rail slope within a safe threshold by constructing a bridge. Railway bridges are bridges especially designed to be crossed by trains. Planning this bridges from the railway tracks, free space of the bridge, until the load received by the bridge is adjusted to the trains that cross the bridge. Axle loads used as a basis for planning must be in accordance with the classification of the path and the largest load operated.5)

Railway bridge planning shall refer to the regulations that apply to each country. In Indonesia, bridge planning refers to Minister of Transportation Regulation No. 60 of $2012^{6}$ ) and for European countries following EN Code 1991-2(2003). ${ }^{7)}$ In each of these regulations set each loading for the planning of the railway bridge.

The purpose of this study compares the results of bridge planning analysis complying code of PM No. 60 of 2012 and Code of EN 1991-2 (2003) on the same bridge span and material. The results of the analysis to be analyzed including the normal plane, shear plane force, moment plane, deflection, and cross-sectional ratio.

\section{RESEARCH METHODOLOGY}

In order to obtain reasonable results, it is necessary that the analysis process follows research flow chart from the beginning process until resulting of loading influence. Flowchart of the study on the effect of increased loading on railroad bridges with different standards can be seen in the flowchart of Figure 1 which refers to the PM 60/2012.

Analytical calculation of the bridge design in this study was done by means of SAP2000 software. ${ }^{8)}$ Span steel bridge for simulation modelling was of 30 meters. 


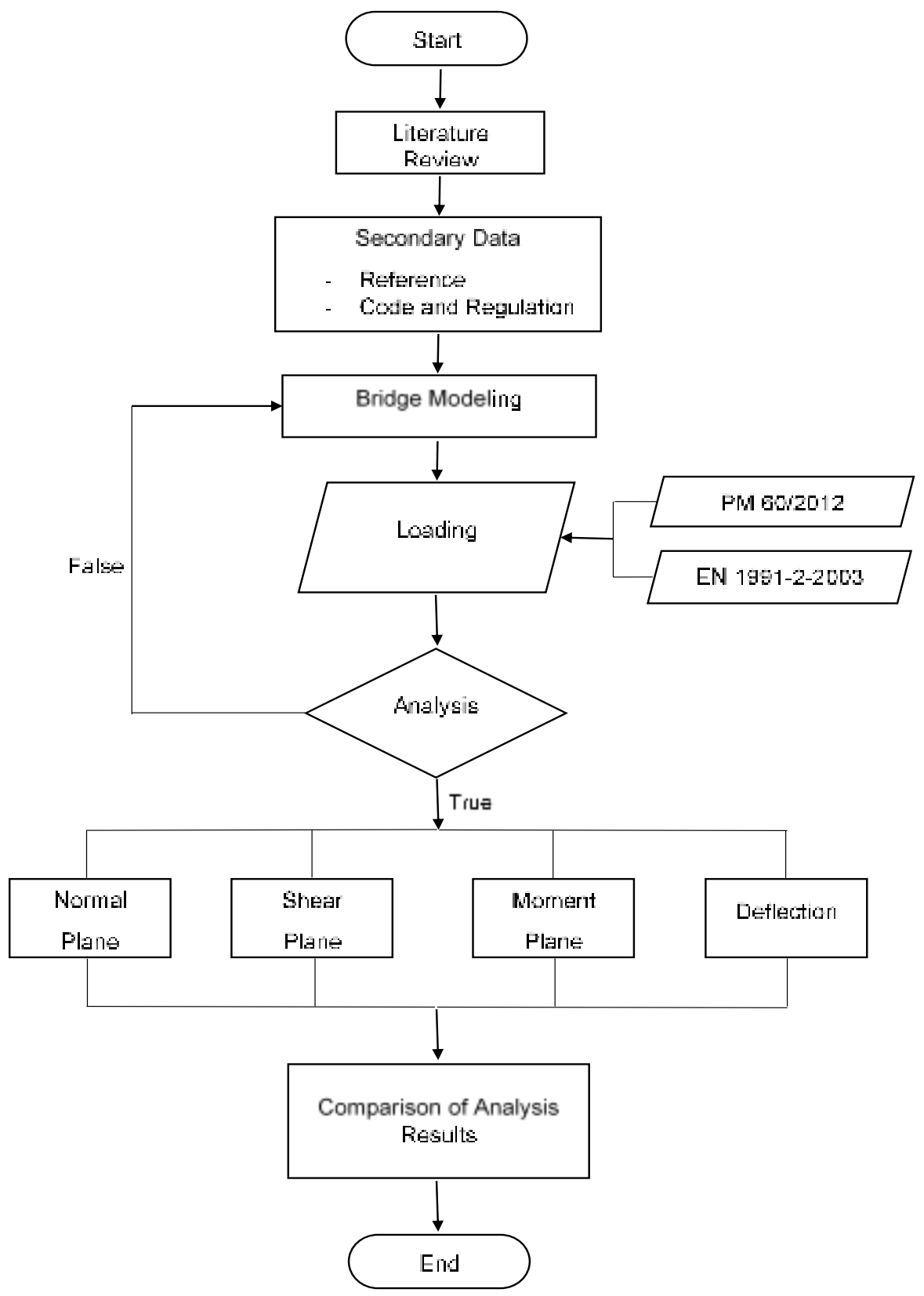

Figure 1

Research Flow Chart

\section{Loading Criteria}

According to its structure, the designed bridge was a truss bridge using permanently designed steel materials. The design loading follows PM 60/20126) and the results was compared to axle loads according to EN1991-2 (2003) ${ }^{7}$. The types of loading that was calculated in the following bridge designs include life load, dead load, impact load, lateral load, wind load, and seismic load.

\section{a. Life Load}

Life load is the largest axle load according to the railway facility operation or the designed load. Life load used in PM $60 / 20126$ ) is an axle load as a moving load which is considered to be an arrangement of trains consisting of 2 locomotives using a tender, which is 12 tons in the form of point loads every $1.2 \mathrm{~m}$ or $8.75 \mathrm{t} / \mathrm{m}$ for bridges series with a span of $30 \mathrm{~m}$. The loading used in railway planning complies the PM 60/2012 standard and it is explained in Figure 2. This designed load was used to analyze railway bridge as reported by Purnomo et. $a l^{8}$ ) but with different loading magnitude and long span bridge. In this research, the loading criteria was compared to european standard (EN Code 1991-2, 2003). 


\section{PAYLOAD DESIGN 1921}

MOVING LOAD

As a moving load, it is assumed a train arrangement consisting of 2 locomotives using a tender, as follows

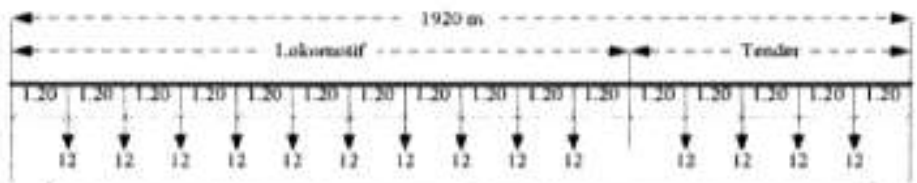

Total Weight 168 tons or $\$ .75$ ton/m

If the number of trains/carts is not certain amount, as follows:

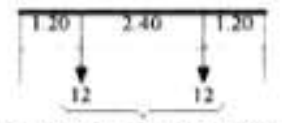

Total of 24 tons or 5 tonim

The train series is always arranged so that for the part that must be calculated its strength is the most critical. If there are 6 or 7 axles that can fit in the count, so the axle load weight should be increased to 15 tons.

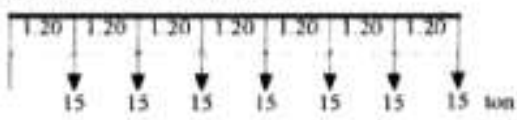

If there are only 5 axles that can fit in the count, so the axle load weight should be increased to 17 tons.

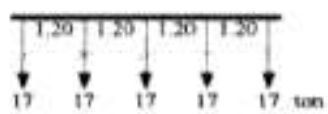

If there are enly 3 axles that can fit in the count, so the axle load weight should be increased to 18 tons.

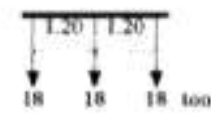

Figure 2.

Scheme of Loading Load

Plan 1921(RM21) ${ }^{6}$

On the other hand, axle loads that exist on Load Model 71 in EN 1991: 2-20037) are a combination of evenly distributed loads of 80 $\mathrm{kN} / \mathrm{m}$ at the beginning and end as well as a centralized load of $250 \mathrm{kN}$ at the center of each distance of $1.6 \mathrm{~m}$. Load Model $71 \mathrm{can}$ be seen in Figure 3.

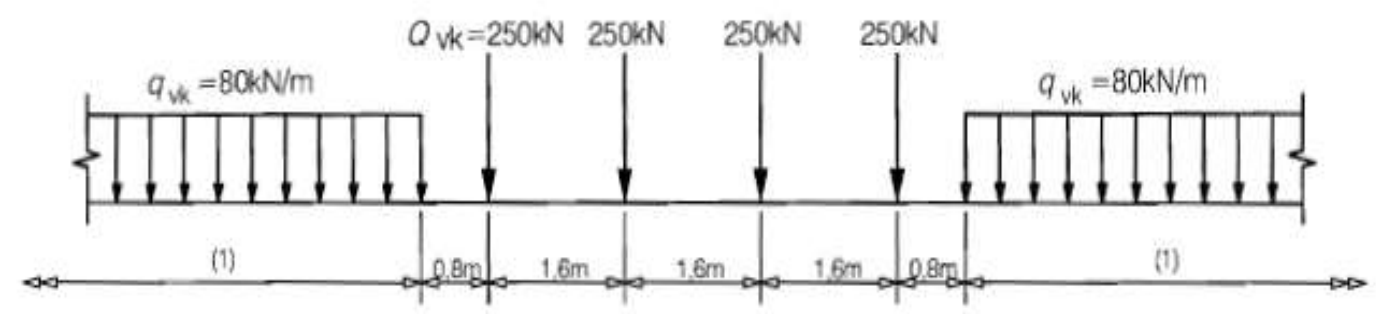

Key

(1) No limitation

Figure 3.

Axle Load Load Model 71 EN 1991-2(2003)7) 


\section{b. Dead Load}

The specific gravity of the material usually used in dead load calculations is:

- Steel density $=78.50 \mathrm{kN} / \mathrm{m} 3$

- Concrete density $=24.00 \mathrm{kN} / \mathrm{m} 3$

For railway widths of $1067 \mathrm{~mm}$, the sleeper dimensions are as follows:

- Length $=2000 \mathrm{~mm}$

- Maximum width $=260 \mathrm{~mm}$

- Maximum height $=220 \mathrm{~mm}$

\section{c. Impact Load}

Impact load considers the magnitude of the length of the bridge span (L). In this case, the impact load factor is directly considered on the steel, and it is calculated as follows

$$
\mathrm{i}=0,3+\frac{25}{50+L}
$$

\section{d. Lateral Load}

Lateral load consists of centrifugal load, train lateral load, brake and traction loads, and longitudinal rail load

- Centrifugal load (a)

Centrifugal loads operate at the center of the train's gravity in the horizontal direction of the rail, and it is calculated as follows

$\alpha=\frac{V^{2}}{127 R}$,

where, $\alpha=$ centrifugal load coefficient, $V=$ maximum velocity, $R=$ curve radius $(\mathrm{m})$

- Train lateral load

The load works on the top and is horizontally perpendicular to the rail direction, The typical value is of $15 \%$ or $20 \%$.

- Brake and traction loads

Brake and traction loads are taken at $25 \%$ of the train load and they work longitudinally at the center of the train's gravity towards the rail.

- Longitudinal rail load

Longitudinal length rail load is basically 10 $\mathrm{kN} / \mathrm{m}$.

\section{e. Wind load}

Wind load works horizontally perpendicular to the train. Typical values are:

- $3.0 \mathrm{kN} / \mathrm{m}^{2}$ on the vertical bridge projection area without a train on it. However, $2.0 \mathrm{kN} / \mathrm{m}^{2}$, on the projection area of the truss framework in the direction of the wind, but it does not include the floor system area.

- $1.5 \mathrm{kN} / \mathrm{m}^{2}$ in the railroad and bridge area, with trains on it, excepting 1.2 $\mathrm{kN} / \mathrm{m}^{2}$ for bridges other than deck/entry girder or composite bridges, while 0.8 $\mathrm{kN} / \mathrm{m}^{2}$ for the truss projection area in the direction the coming of the wind.

\section{f. Seismic Load}

Seismic load shall refer to earthquake spectra designed by the Ministry of Public Work and Public Housing.

\section{Loading Combination}

Loading combination used complys the Indonesian National Standard which is guided by SNI 1725: 20169) concerning loading of bridges.

\section{Deflection}

Deflection is defined as the deviation magnitude that shall not exceed requirement coefficient of the theoretical length. Allowable deflection requirements shall comply PM $60 / 2012^{6)}$ and it can be seen in Table 1.

Tabel 1

Maximum Deflection Coeffisient for Steel Bridge ${ }^{6}[\mathrm{~B} 1]$

\begin{tabular}{ccccc}
\hline Type & \multicolumn{3}{c}{ Girder } & Truss \\
\hline Type of train & $\mathrm{L}(\mathrm{m})$ & $\mathrm{L}<50$ & $\mathrm{~L} \geq 50$ & All Truss \\
Locomo tive & & $\mathrm{L} / 800$ & $\mathrm{~L} / 700$ & $\mathrm{~L} / 1000$ \\
& $\mathrm{~V}(\mathrm{~km} / \mathrm{h})$ & $\mathrm{V}<100$ & $\mathrm{~L} / 700$ & \\
& & $100<\mathrm{V} \leq 130$ & $\mathrm{~L} / 800$ & $\mathrm{~L} / 700$ \\
& $100<\mathrm{V} \leq 130$ & $\mathrm{~L} / 1100$ & $\mathrm{~L} / 900$ & \\
\hline
\end{tabular}




\section{RESULTS AND DISCUSSION}

Results of the analysis show that the steel truss bridges use IWF profiles with right angle. Dimensions and grade of the IWF profiles are listed in Table 2.

Table 2.

Profile of Cross Section Bridge

\begin{tabular}{cccc}
\hline No & Kode & Dimensi $(\mathrm{mm})$ & Grade \\
\hline 1 & MM-1 & IWF $400 \times 400 \times 25 \times 30$ & SM 490 YB \\
2 & MM-2 & IWF $300 \times 300 \times 25 \times 30$ & SM 490 YB \\
3 & MM-3 & IWF $300 \times 300 \times 16 \times 25$ & SM 490 YB \\
4 & MD-1 & IWF $450 \times 200 \times 9 \times 16$ & SM 490 YB \\
5 & ML-1 & IWF $600 \times 200 \times 16 \times 25$ & SM 490 YB \\
6 & ML-2 & IWF $300 \times 150 \times 12 \times 19$ & SM 490 YB \\
7 & RD-1 & IWF $300 \times 300 \times 16 \times 25$ & SM 490 YB \\
8 & RD-2 & IWF $300 \times 300 \times 16 \times 19$ & SM 490 YB \\
9 & RD-3 & IWF $300 \times 300 \times 9 \times 12$ & SM 490 YB \\
10 & BR-1 & L $100 \times 100 \times 10$ & SM 490 YB \\
11 & BR-2 & IWF $150 \times 150 \times 6 \times 6$ & SM 490 YB \\
\hline
\end{tabular}

Further, the designated IWF profiles are modelled into SAP2000 software. The steel frame of railroad bridge that are be modelled into computer program can be seen in Table 3 and Table 4.

Table 3.

Railway Technical Data

\begin{tabular}{ll}
\hline \multicolumn{1}{c}{ Railway Technical Data } \\
\hline Tipe of Rail & $:$ R 60 \\
Rail width & $: 1067 \mathrm{~mm}$ \\
Type of sleeper & $:$ Beton \\
Sleeper spacing & $: 60 \mathrm{~cm}$ \\
Maximum speed & $: 120 \mathrm{~km} / \mathrm{jam}$ \\
Modulus of Elasticity & $: 2.1 \times 10^{6} \mathrm{~km} / \mathrm{cm}^{2}$ \\
Axel load (PM 60) & $: 12 \mathrm{ton}$ \\
\hline
\end{tabular}

Tabel 4.

Bridge Data

\begin{tabular}{ll}
\hline \multicolumn{2}{c}{ Bridge Data } \\
\hline - Type of bridge & $:$ Steel Truss \\
- Width of bridge & $: 4 \mathrm{~m}$ \\
- Length of bridge & $: 30 \mathrm{~m}$ \\
\hline
\end{tabular}

Rail sleepers are also input parameters for the software. The dimensions of the rail sleeper for the rail with the width of $1067 \mathrm{~mm}$ and the weight of $274.56 \mathrm{~kg} /$ piece with the sleeper spacing of $0.6 \mathrm{~m}$ and the bridge length of $30 \mathrm{~m}$, can result in a uniform load of $457.6 \mathrm{~kg} / \mathrm{m}$. This number comes from the following calculation.

$$
\begin{aligned}
\text { Q sleeper } & =\frac{W x \text { ammount of sleeper }}{L \text { bridge }} \\
& =\frac{274,56 x 30 / 0,6}{30} \\
& =457.6 \mathrm{~kg} / \mathrm{m}
\end{aligned}
$$

It has been known that the rail type of $R 60$ with $Q=60.34 \mathrm{~kg} / \mathrm{m}$ are utilized for the design. Therefore, it can be obtained that the rail load for one lane is of $120.68 \mathrm{~kg} / \mathrm{m}$. Based on sleeper and rail loads, it can be concluded that the dead load for bridge is as big as of 0.289 tons $/ \mathrm{m}$. The aformention loads become an input parameter to verify and to compare calculation of the two standards.

Based on PM 60/20126), it is planned that the weight of 1 axle is 12 tons with a spacing between axles of $1.2 \mathrm{~m}$. Total weight is 168 tons or 8.75 tons $/ \mathrm{m}$. Therefore, the axle load that works in one rail is of 4,375 tons $/ \mathrm{m}$. Impact loads work on the railroad tracks and are in line with axle loads. This load is obtained by multiplying the $i$ factor against the train load. In this case, the train load (locomotive and tender) is 12 tons. As a results of the calculation, it can be obtained that an impact load of 2.68 tons $/ \mathrm{m}$ is reasonable.

Lateral load used is of 0.875 tons $/ \mathrm{m}$ and braking and traction loads is of 1.094 tons $/ \mathrm{m}$ were used to analyzed the structures. In addition, wind load is of $0.8 \mathrm{kN} / \mathrm{m}^{2}$ worked to the truss. With the aformention parameters, therefore the load combinations 
The Comparative Study Of Railway Bridge Design Load Between Pm 60/2012 And En 1991: 2-2003 (Willy Barasa, Thiya Fiantika, Dwi Agus Purnomo, Wimpie A N Aspar)

from the two standards can be obtained. The results of the calculation are presented in Table 5. It can be seen in Table 5 that here are 2 types of loading in EN 1991, namely (a) and (b). This happens because loading refers to Load Model 71 in EN 1991, where there is a difference in uniform load at every spacing of $6.4 \mathrm{~m}$.

Table 5.

Comparison of PM 60 and EN 1991 loading

\begin{tabular}{llll}
\hline No & Load & $\begin{array}{l}\text { PM 60 } \\
\text { (ton } / \mathrm{m})\end{array}$ & $\begin{array}{l}\text { EN 1991 } \\
\text { (ton } / \mathrm{m} \text { ) }\end{array}$ \\
\hline 1 & Dead load & 0.289 & 0.289
\end{tabular}

$\begin{array}{llll}2 & \text { Axle load } & 4.375 & \begin{array}{l}\text { a. } 4.079 \\ \text { b. } 7.967\end{array} \\ 3 & \text { Impact load } & 2.68 & \begin{array}{l}\text { a. } 2.498 \\ \text { b. } 4.88\end{array} \\ 4 & \text { Lateral load } & 0.875 & \begin{array}{l}\text { a. } 0.816 \\ \text { b. } 1.593\end{array} \\ 5 & \begin{array}{l}\text { Breaking/Tract } \\ \text { ion load }\end{array} & \begin{array}{l}\text { a. } 1.094 \\ \text { b. } 1.992\end{array} \\ 6 & \text { Wind load } & 0.08 & \begin{array}{l}\text { b.08 } \\ \hline\end{array}\end{array}$

Configuration of the steel truss railway bridges that were modeled in this analysis are shown Figure 4 up to Figure 7.

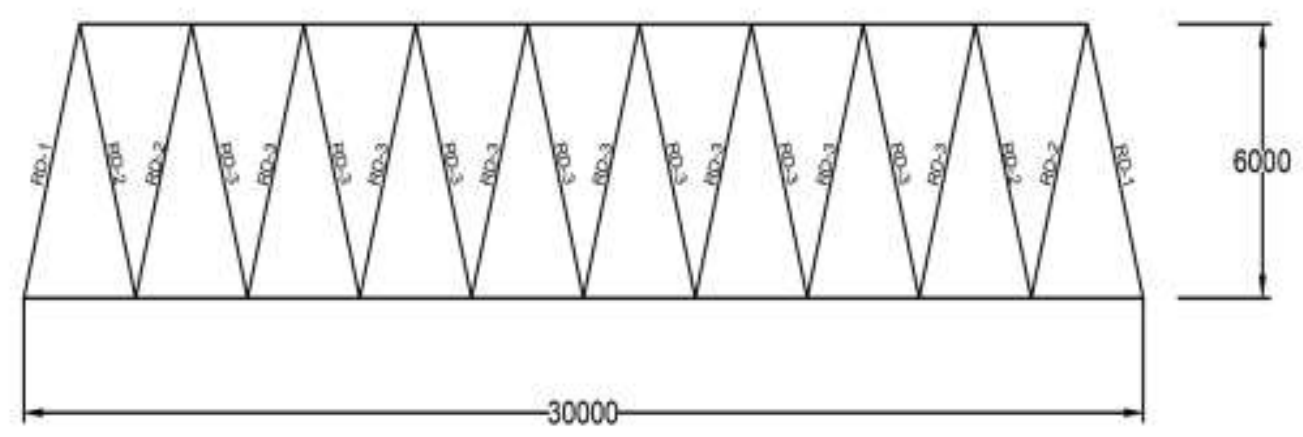

Figure 4.

Side View of Truss Bridge

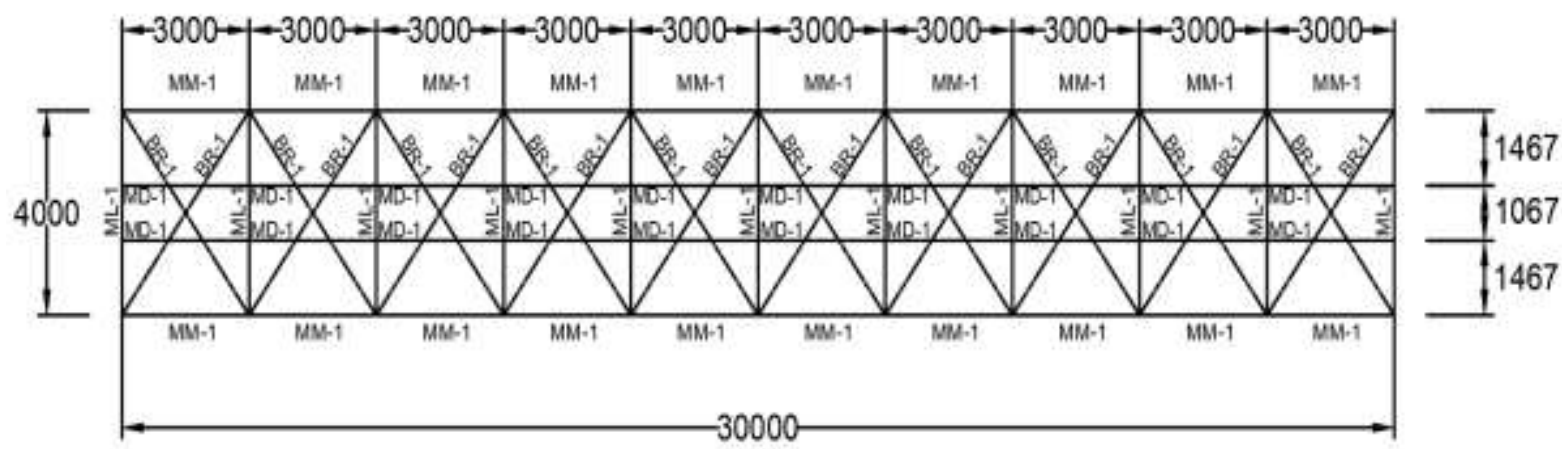

Figure 5

The Lower Part of Railway Bridge

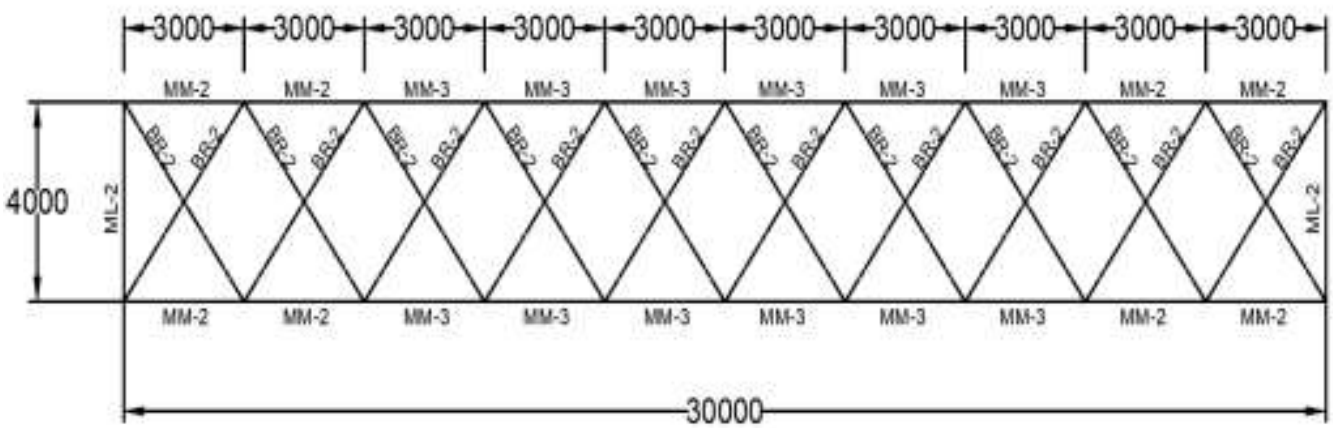

Figure 6.

Top of the railway bridge 


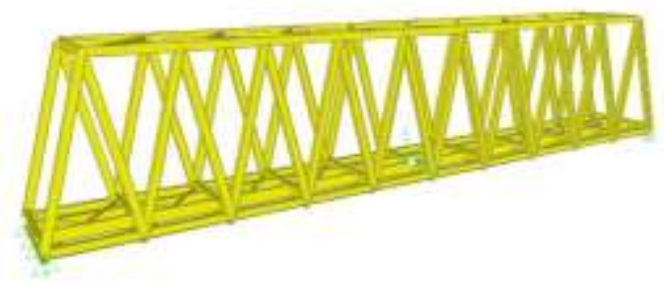

Figure 7.

Bridge 3D Modeling

The loading combination of this steel truss railway bridge, using the combination of loading set forth in SNI 1725: 2016, is a combination of loading "Serviceability II"6) and as follows:

Comb L:

$\mathrm{DL}+1.3 \mathrm{BG}+1 \cdot 3 \mathrm{BK}+1 \cdot 3 \mathrm{BR}+1 \cdot 3 \mathrm{BL}+\mathrm{BAL}$

Comb R:

$\mathrm{DL}+1.3 \mathrm{BG}+1.3 \mathrm{BK}+1.3 \mathrm{BR}+1.3 \mathrm{BL}+\mathrm{BAR}$

Information :

$\mathrm{DL} \quad=$ Dead Load

BG = Axle Load

BK = Impact Load

BR = Breaking \& Traction Load

$\mathrm{BL}=$ Lateral Load

BAL = Left wind load

BAR = Right wind load

It is known that structural analysis is carried out on a $30 \mathrm{~m}$ span steel truss railway bridge with normal field output, shear field, moment field, deflection, and crosssection ratio. With this condition the structural analysis results in a various phenomenon. The largest normal force that occurs in the analysis of the bridge structure is at frame 68 with an axial force of 210.89 tons. Normal force plane resulted from the calculation can be seen in Figure 8.

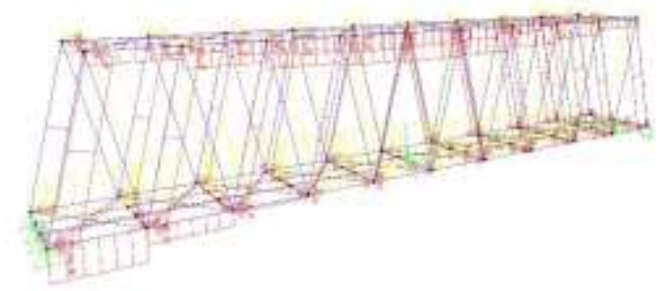

Figure 8.

Normal Force Plane at a Load Combination Comb L

The biggest shear force that occurs in the analysis of the bridge structure is at frame 63 with a shear force of 32.371 tons. Shear force plane resulted from the calculation can be seen in Figure 9.

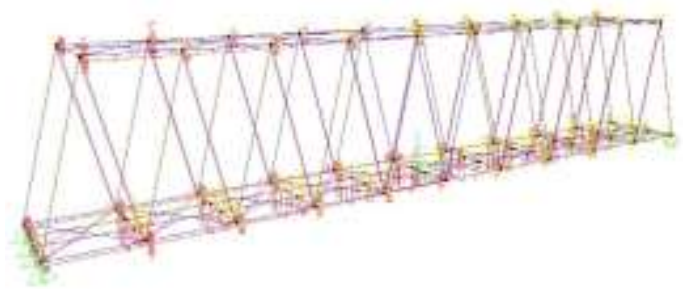

Figure 9.

Shear Field at Load Combination Comb L

The biggest moment force that occurs in the analysis of the bridge structure is at frame 62, station 2.534 with a magnitude of shear force that is of 41.582 tons. The result is illustrated in Figure 10.

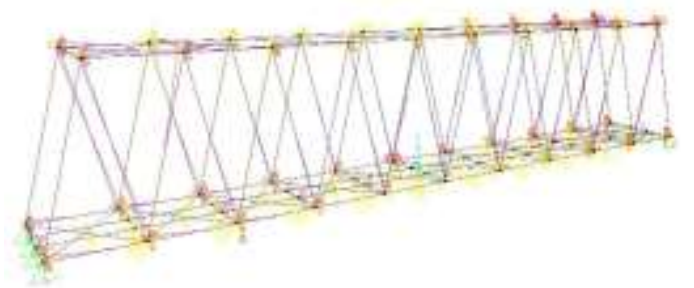

Figure 10.

Moment Field at Load Combination Comb L

The largest deflection that occurs in the analysis of the bridge structure is at joint 105 with deflection of $37.86 \mathrm{~mm}$. This is shown in Figure 11. Maximum permit deflection limit is $\mathrm{L} / 1000$. Therefore, the calculation results in the maximum deflection value of $30 \mathrm{~mm}$.

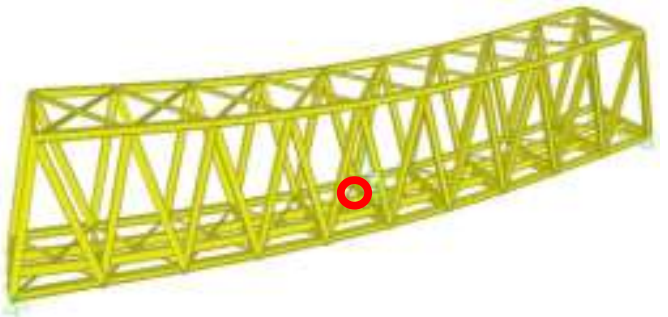

Figure 11.

Deflection Analysis

From the results of the analysis of the two bridges with different loading, a comparison of the normal plane, shear, moment and deflection with a predetermined loading combination can be obtained. The values obtained from analysis is illustrated in graphical form in Figure 12. The Figure 12 distinguishes combination of the Comb $L$ and Comb R loading. Numerically of the analysis is presented in Table 6 and Table 7. Each of the results of structural analysis has increased due to changes in loading from PM 60/2012 to EN 1991: 2-2003. The difference is then drawn into a graph which can be seen in Figure 12. 
Table 6

Structure Analysis Result of Comb L

\begin{tabular}{lllll}
\hline $\begin{array}{l}\text { Structure } \\
\text { Analysis }\end{array}$ & $\begin{array}{c}\text { Normal } \\
\text { Filed } \\
\text { ton }\end{array}$ & $\begin{array}{c}\text { Shear } \\
\text { Field } \\
\text { ton }\end{array}$ & $\begin{array}{c}\text { Momen } \\
\text { t Field } \\
\text { tonm }\end{array}$ & $\begin{array}{c}\text { Deflec } \\
\text { tion } \\
\mathbf{m m}\end{array}$ \\
\hline $\begin{array}{l}\text { PM 60 th } \\
\mathbf{2 0 1 2}\end{array}$ & & & & \\
Scale & 210.89 & 32.371 & 41.582 & 37.86 \\
Station & 0 & 0 & 2.534 & - \\
Frame/ & 68 & 63 & 62 & 105 \\
Joint & & & & \\
EN & & & & \\
1991:2- & & & & \\
$\mathbf{2 0 0 3}$ & & 51.823 & 70.94 & 49.4 \\
Scale & 285.62 & 5 & 1.467 & - \\
Station & 0 & 4 & 57 & 104 \\
Frame/Jo & 67 & 57 & 57 \\
int & 67 & & & \\
\hline
\end{tabular}

Tabel 7.

Structure Analysis Result of Comb R

\begin{tabular}{lllll}
\hline $\begin{array}{l}\text { Structure } \\
\text { Analysis }\end{array}$ & $\begin{array}{c}\text { Normal } \\
\text { Field } \\
\text { ton }\end{array}$ & $\begin{array}{c}\text { Shear } \\
\text { Field } \\
\text { ton }\end{array}$ & $\begin{array}{c}\text { Momen } \\
\text { t Field } \\
\text { tonm }\end{array}$ & $\begin{array}{c}\text { Deflec } \\
\text { tion } \\
\text { mm }\end{array}$ \\
\hline $\begin{array}{l}\text { PM 60 th } \\
\mathbf{2 0 1 2}\end{array}$ & & & & \\
Scale & 263.01 & 32.25 & 41.94 & 37.851 \\
Station & 5 & 8 & 1.467 & - \\
Frame/ & 0 & 4 & 56 & 105 \\
Joint & 75 & 55 & 56 & \\
EN & & & & \\
1991:2- & & & & \\
$\mathbf{2 0 0 3}$ & & & & \\
Scale & 343.16 & 52.93 & 71.526 & 49.422 \\
Station & 0 & 2 & 1.467 & - \\
Frame/ & 75 & 5 & 57 & $104]$ \\
Joint & 75 & 57 & 57 \\
\hline
\end{tabular}

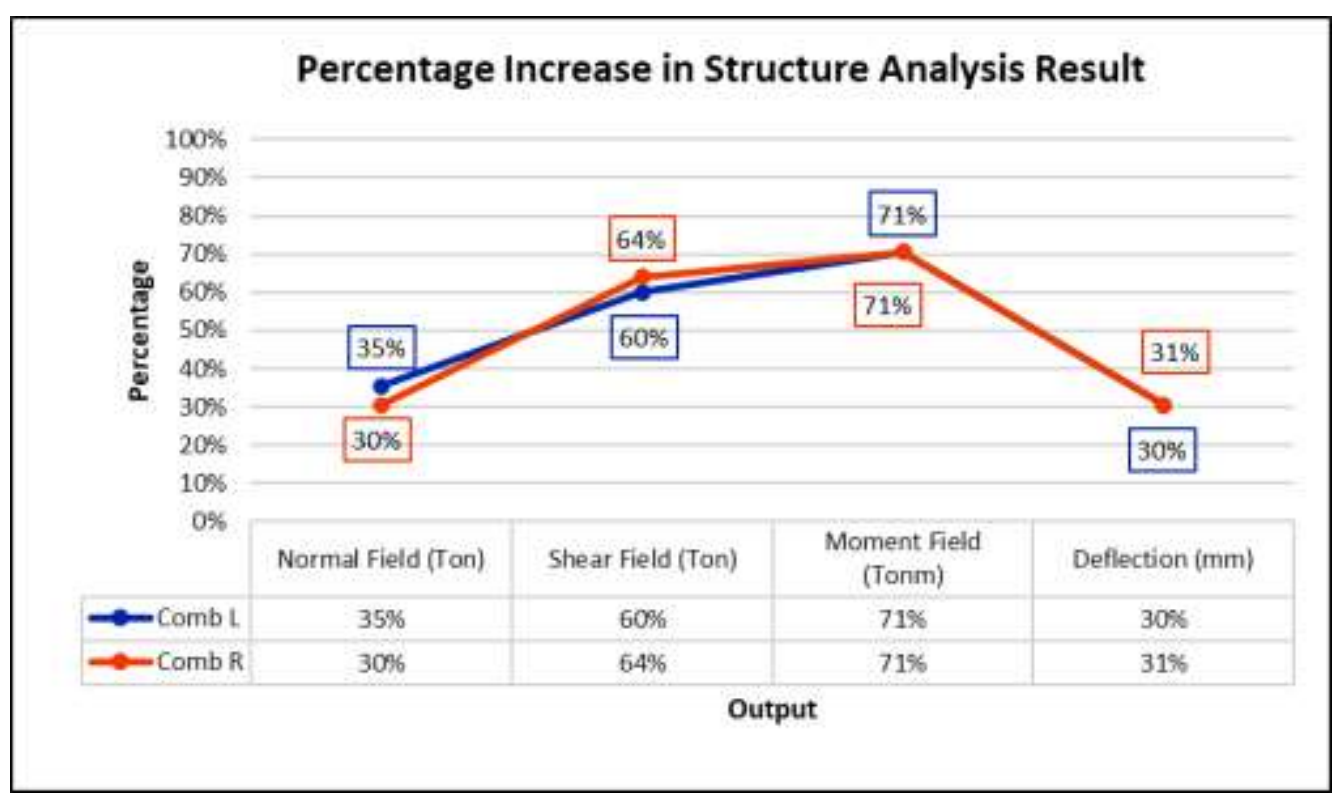

Figure 12.

Percentage Graph Increase in Results of Structural Analysis

\section{CONCLUSION}

The results of the analysis show that the bridge planning with the same dimensions and material but with different loading increases in the normal field, shear field, moment field, and deflection. The increase of the normal plane, shear plane, moment plane, and deflection is of $35.4 \%$, $60.1 \%, 70.6 \%$, and $30.5 \%$, respectively. The percentage increase was obtained from the difference in the results of the analysis on loading using PM 60 of 2012 and EN 1991: 2-2003. Comparison of the results of the analysis using two different loading combinations, is namely the combination of loading $\mathrm{L}$ and Comb $\mathrm{R}$. Results of combination of Comb $L$ is in line with loading combination of Comb $R$. The percentage increase in the normal plane, shear plane, moment plane, and deflection is of $30.5 \%$, $64.1 \%, 70.5 \%$, and $30.6 \%$, respectively. Whereas in the combination of Comb $R$ loading the percentage increase were $30 \%$, $64 \%, 71 \%$, and $31 \%$, respectively. 


\section{ACKNOWLEDGEMENT}

This paper is part of a the research done in the Center of Technology for Transportation Systems and Infrastructure Agency for the Assessment and Application of Technology. The research can be carried out by funding from the 2019 BPPT DIPA in "the Study and Application of Transportation Systems and Infrastructure Technology". Without financial support from BPPT, this research would have been impossible. The authors would like to thank for the financial support. The authors would also like to thank the reviewers who actively provides direction and suggestion.

\section{REFERENCES}

1. Nasution M Nur, Transportation Management, Second Edition, Publisher: Ghalia Indonesia 2004.

2. Gitgita, What is the History of Railway in Indonesia, http://sejarahunik.net/ sejarah/bagaimana-sejarah-kereta-apiindonesia.html., posted at Januari 13, 2018,

3. Directorate General of Railway - Ministry of Transportation, National Railway Master Plan, April 11, 2011.

4. Rosyidi, SAP, 2015, Rekayasa Jalan Kereta Api (Tinjauan Struktur Jalan Rel),
Yogyakarta, Penerbit Lembaga Penelitian, Publikasi dan Pengabdian Masyarakat Universitas Muhammdiyah Yogyakarta (LP3M UMY).

5. Muspitasari, Tri., Sulistyowati, Indah., Kumara, Widi, Evaluasi Peraturan Pembebanan Gandar Kereta Api di Pulau Jawa Terhadap Kondisi Aktual, Jurnal Teknik Sipil, Universitas Atma Jaya Yogyakarta, Vol.14, No. 13, 2017.

6. Minister of Transportation Regulation No. 60 of 2012 Railway Technical Requirements.

7. European Standard 1991:2 (2003). Traffic Loads on Bridge. European Committee for Standardization. Brussels. Belgia.

8. Purnomo, Dwi Agus., Utomo, D. P., Waseso, A. B., and Marindaa, M., Analysis of Railway Bridge Model for I Girder Type and Warren Truss Type Journal of Industrial Technology Assessments, Vol. 14, No. 1, pp. 47-58. 2020.

9. SAP2000(R), 1997 Integrated Finite Elements Analysis and Design of Structures, TUTORIAL MANUAL, Version 6.1, Computers and Structures, Inc., Berkeley, California, USA.

10.Standar Nasional Indonesia (SNI) 1725:2016, ICS 93.040, Badan Standardisasi Nasional (BSN), 2016, tentang Pembebanan untuk Jembatan. 